\title{
Particle-size Distribution and Bioaccessibility of Metals-loaded in Street Dust of Urban Center in Southwest Nigeria
}

Emmanuel Gbenga Olumayede ${ }^{1 *}$; Thompson Faraday Ediagbonya ${ }^{2}$; Chuckuembe Ojiodu ${ }^{3}$; Ilemobayo Oguntimehin²; Olujinmi Moses Folarin²; James Majebi Okuo ; Olushola Sunday Ayanda ${ }^{1}$

1. Department of Industrial Chemistry, Federal University, Oye - Ekiti, Nigeria

2. Department of Chemical Sciences, Ondo State University of Science and Technology,

Okitipupa, Ondo State, Nigeria.

3. Department of Science Laboratory, Yaba College of Technology, Lagos Nigeria

4. Department of Chemistry, University of Benin, Benin City

*Corresponding address: emmanuel.olumavede@fuove.edu.ng +23408034345141.

\begin{abstract}
In this study, we attempted to verify the hypothesis that total metals bound to dust of different particle sizes may reflect pollution levels, but cannot predict its bioavailability and risks in human health assessments. Dust samples were collected using active sampling method; during the dry season months of November, 2014 to March, 2015 at different locations in Akure $\left(7^{\circ} 10^{\prime} \mathrm{N}\right.$ and $\left.5^{\circ} 15^{\prime} \mathrm{E}\right)$. The samples were sorted into different particle sizes $(<10 \mu \mathrm{m}, 10-50 \mu \mathrm{m}$, $>50 \mu \mathrm{m}$ ), analyzed for some physicochemical properties and assessed for metals bioavailability using two-step physiological extraction method. The amount of metals $(\mathrm{Cd}, \mathrm{Cu}, \mathrm{Cr}, \mathrm{Ni}, \mathrm{Pb}, \mathrm{Zn}$ and $\mathrm{Mn}$ ) released in each particle sizes were determined using Perkin-Elmer 6000 Inductively Coupled Plasma - Atomic Emission Spectrometry (ICP-AES) analysis. The results showed that bioavailability of some metals $(\mathrm{Cd}, \mathrm{Ni}, \mathrm{Pb}$, and $\mathrm{Zn})$ decreases with increasing particle sizes, however, the reverse trend was observed for $\mathrm{Mn}, \mathrm{Cu}$ and $\mathrm{Fe}$ concentrations. This may be attributed to some combination of physicochemical characteristics of the dust and metal speciation. Hence, it was concluded that metal bioaccessibility in dust can best be described by the knowledge of physicochemical characteristics. The exposure dose of the metals showed that cancer risks due to inhalation were very high when compared to other exposure routes (ingestion and dermal contact). The calculated non-cancer (HQ) and cancer risk (HI) for humans in the area showed values higher than unity, indicating possibility of the metals' body burden.
\end{abstract}

Key Words: dust; bioavailability; particle sizes; heavy metals; health risk; exposure 


\section{Introduction}

Dusts are finely divided particulate matters that are generated during human activities; sweeping, quarrying, metal fabrication, etc and are readily lifted by wind. Once generated and released to the atmosphere, they travel long distances from emission point source by turbulent atmospheric currents and finally settles either by gravity under condition of calm or brought to the surface by precipitation [1]. In the course of transportation, the suspended metals are loaded to particulates; hence the dust creates a reserve pool of metals in urban atmosphere [2]. In recent time, nonoccupational exposures to dusts in urban atmosphere worldwide have aroused much attention due to its associated health effects. For example, on breathing air containing metal laden particles, the smaller particles can reach the wind-pipe (trachea) and eventually dissolve in the blood stream. According to TUC [3], the two most serious health problems associated with dust are; cancers of the lungs, throat and nose, and other lung conditions called chronic obstructive pulmonary diseases (COPD) which include chronic bronchitis and emphysema. A report in 2007 gave a likely figure of between 7,000 and 8,000 for cancers of the lung and the nose due to exposure dust at work [2].

Numerous researchers have investigated elemental compositions of suspended particulate matters in cities worldwide; Monterry, Mexico [4], Tehran, Iran [5], Nigerian cities [6-10]. In most of these studies, it was observed that urban dusts were typically elevated by total metal concentrations above the standard limits prescribed by WHO for respirable dust in most cities. Studies have indicated that fine particles are more harmful than coarse particles $[11,12]$. It has also been suggested that there exist causal relationship between inhalable and metal concentrations in the atmosphere [13].

It has been reported that metals burdened to dust particles have varied distributions in different geochemical phases [14] and should be considered when assessing their risks. According to Ruby et al [15], some metals and their compounds are not readily soluble; therefore toxicity tests based on their solubility may overestimate the health risk associated with them. Bioaccessibility is a closely related term which refers to the fraction of contaminant that is dissolved in the digestive fluids and assumed to be available for absorption and bioavailable [16]. Similarly, it has also been reported that total concentration of metals can reflect the pollution level of dust, but cannot predict its bioavailability [17]. It is therefore imperatively necessary to investigate speciation of metals in dust; this is to enable us determine accurately the bioaccessibility and risks posed by individual metals.

To date, a lot of investigators have studied human bioaccessibility of metals using several methods and tools; including in vivo and in vitro digestion models of [16, 18-23]. The in vivo methods (animal models) depend on the toxico-kinetic profile of the chemical of interest, chemical concentrations in dust and sensitivity of analytical methods. These models provide valuable contaminant bioavailability data but have the disadvantage of being time-consuming, expensive, requiring weeks or months to complete, and requiring highly specialized personnel [24]. On its part, the In vitro methods are laboratory extraction tests; in which the gastrointestinal condition is mimiced using synthetic solution [23], including physiologically-based extraction test (PBET), simulator of the human intestinal microbial ecosystem (SHIME), The Netherlands National Institute of Public Health and the Environment (RIVM) method, Fed ORganic Estimation human Simulation Test (FOREhST), and in vitro gastrointestinal (IVG) method. The method is humane and less expensive, and provides a quicker assessment and now widely used to assess the relative bioavailability [25]. For example, Luo et al [26] reported the 
bioaccessibility and health risks through oral ingestion of trace metals in urban street dust using simplified test (SBET) simulating only gastric acid conditions. Similarly, this method has been used to determine bioaccessibility of metals such as lead, cadmium and arsenic in different soils and animals; swine [27], rodents [28, 29] and rabbits [30]. Meanwhile, it is assumed that bioaccessibility of metal-bound dust can be predicted from solid phase speciation.

Unfortunately, the above assumptions have not been investigated in the study of risks associated with metals-loaded dust in Nigeria cities. This report will fill such a gap. The study is part of the Urban Dust Monitoring and Health Risk Assessment (UDMAHRA) project, initiated to monitor urban dust and its potential health risks in Nigerian cities. As studies continued to unravel the characteristics and potential health risks of dust in urban atmosphere, the aim of this contribution was to investigating the relative bioavailability and toxic potentials of some heavy metal contents of suspended dust samples in a fast growing city (Akure: $7^{\circ} 10^{\prime} \mathrm{N}$ and $5^{\circ} 15^{\prime} \mathrm{E}$ ). The objectives of this study include (i) assessing the particle size distribution of dusts of the monitoring sites, (ii) evaluating the bioavailability of metals-loaded dust samples collected in atmosphere of Nigeria city, and (iii) assessing the carcinogenic and non-carcinogenic toxicity potentials of the metals on the basis of the relative content of the fractions. The novelty of this study is that we attempt to incorporate adjusted relative bioavailability to human health risk assessments. It is envisaged that the data generated in this study will stimulate environmental concerns on the impacts of dust particles and be translated into improved respiratory health among the people.

\section{Materials and Method}

\section{Site Description}

Akure $\left(7^{\circ} 10^{\prime} \mathrm{N}\right.$ and $\left.5^{\circ} 15^{\prime} \mathrm{E}\right)$ is situated in the rainforest zone of southwest, Nigeria, with population of about 360,268 people [31]. It is one of the fastest growing urban settlements in the south western Nigeria. It serves as a transitory link to northern and Eastern parts of the country and with many industrial plants. The climatic conditions of Nigeria and Akure have been described elsewhere [32].

\section{Sampling routine and sampling sites}

Five outdoor selected sampling sites within Akure and at an unpolluted (background) area were selected for study. The sampling sites for this study were carefully chosen to reflect different human activities impacting the environments. This is to ensure that the sampling program covered any variation in particle concentrations. The description, co-ordinates and air quality of the sampling sites are shown in Table 1.

\section{Dust Sampling}

The dust sampling method previously described by $\mathrm{Yu}$ et al [33] was used in this study. Briefly, street dusts were collected by sweeping many areas of $1 \mathrm{x}^{2} \mathrm{~m}^{2}$ surfaces adjacent to the edge of the road, with a dustpan and brushes. The samples collected were stored in the self-sealed plastic container. It was then transported to laboratory for analysis.

\section{Physicochemical Characterization of Dust particles}


In the laboratory, samples were air dried for 3 days. Samples from the same location were thoroughly mixed, to obtain sufficient size and representative samples, and then sieved into different particle sizes (classified as; $<10,10-50$, and $>50 \mu \mathrm{m}$ ). It was then subjected to various analyses which include; physicochemical properties (mass load, $\mathrm{pH}$, Organic matter, conductivity), geochemical analysis and minerals composition (X-Ray Diffraction). The dust concentrations were estimated from trace element measurements and calculation using the following equation:

Dust $=1.89 * \mathrm{Al}+1.21 * \mathrm{~K}+1.95 * \mathrm{Ca}+1.66 * \mathrm{Mg}+1.7 * \mathrm{Ti}+2.14+\mathrm{Si} * 1.42 * \mathrm{Fe}$

Organic matter content was measured via loss on ignition at $500^{\circ} \mathrm{C}$ for $3 \mathrm{~h}$. Dust conductivity was measured after equilibration for $30 \mathrm{~min}$ in deionized water at a 10:1 liquid: dust ratio with a Hanna Instruments 8033 electrode (Hanna Instruments, Laval, Canada) calibrated at $25^{\circ} \mathrm{C}$ and $1413 \mu \mathrm{Scm}^{-1}$. The supernatants of these solutions were then measured for $\mathrm{P}^{\mathrm{H}}$ using a glass electrode calibrated at $\mathrm{pH} 4$ and 10. Speciation of metals was carried out in dust particles using a modification of the European Communities Bureau of Reference (BRC) sequential extraction [35].

\section{Bio accessibility (Oral bioavailability) test}

The relative oral bioavailability (bio accessibility) of each metal in dust particles was determined using the In vitro method as described by Ruby et al [16] and Oomen et al [23]. The method is a two-step physiological based extraction test that investigates the solubility of metals in laboratory test. It is assumed to capture rate-limiting component controlling RBA. Briefly describe here, the test fluid for this study is the Gamble's solution $\left(\mathrm{P}^{\mathrm{H}}=7.4\right)$. The chemical composition is given below (Table 2). The initial $\mathrm{P}^{\mathrm{H}}$ of the solution was adjusted with $260 \mu \mathrm{L} / \mathrm{L}$ of $25 \% \mathrm{HCl}$ solution. The dust powders were exposed to the test solution and the amounts of metals dissolved/ released concentrations in synthetic body fluid were analyzed for geochemical analysis.

The metal contents analysis of the samples was carried out using a Perkin-Elmer 6000 Inductively Coupled Plasma - Atomic Emission Spectrometry (ICP-AES), before quantification. The ICP-AES Instrument was calibrated daily. The ICP-AES instrument was calibrated daily. A standard curve was deemed acceptable only if the $r^{2}$ (coefficient of determination) was greater than $95 \%$. After every 10 samples a standard was analyzed as a sample. If the variation between this sample and standard concentration was more than $5 \%$ the instrument was recalibrated. Instrument accuracy was checked daily by analyzing a $2 \%$ NIST standard to ensure that the percent difference between certified and measured concentrations was between $70 \%$ and $120 \%$. Method detection limits (MDLs) for the ICP-AES were calculated by repeated analysis of a low concentration sample. MDL is defined as three times the standard deviation of the concentrations obtained in the seven runs. Metal concentrations in the process blanks were either below or of the same magnitude as the MDLs. To account for trace levels of background contamination, the mass of metal in the field blank was subtracted from the mass collected on the various stages of sampling. Extraction efficiencies were calculated by measuring metal concentrations after spiking a 10\% nitric acid solution with urban particulate matter (NIST SRM 1648).

ICP-MS 
We calculated the bio accessibility of $\mathrm{Pb}, \mathrm{Cd}, \mathrm{Cr}, \mathrm{Cu}, \mathrm{Fe}, \mathrm{Ni}$ and $\mathrm{Zn}$ using the formula below adapted from USEPA [36].

Bioaccessibility $(\%)=\frac{(\text { concentration in extract, } \mu \mathrm{g} / \mathrm{L}) \times(\text { volume of extract, } \mathrm{L}) \times 100}{\text { (Concentration in dust, } \mu \mathrm{g} / \mathrm{kg}) \times(\text { mass of dust used, g) }}$

The relative bioavailability (F) of dust bound metals was estimated from the site specific screening values calculated using equation 2

Screening Value $($ RBA adjusted $)=$ Screening Value $/$ RBA

(3) $[37]$

\section{Incorporation into Human Health Risk Assessment}

The relative bioavailability ( $\mathrm{F}$ route) was applied as a factor modifying the concentration in equation for calculating exposures from dust via ingestion, inhalation and dermal contact using equation (4) - (6) [38].

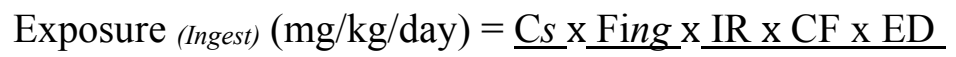

$\mathrm{BW} \times \mathrm{AT}$

Exposure $_{\text {(nhaled dose) }}(\mathrm{mg} / \mathrm{kg} / \mathrm{day})=\underline{\mathrm{Cs} \times \mathrm{Finh} \times \mathrm{InhR} \times \mathrm{EF} \times \mathrm{ED} \times(1 / \mathrm{PEF} \times 1 / \mathrm{VF})}$.

$\mathrm{BW} \times \mathrm{AT}$

Exposure ${ }_{(\text {Absorbed })}(\mathrm{mg} / \mathrm{kg} /$ day $)=\underline{\mathrm{Cs} \times \mathrm{ABS} \times \mathrm{SA} \times \mathrm{CF} \times \mathrm{AF} \times \mathrm{EF} \times \mathrm{ED}}$

BW x AT

Where:

$\mathrm{Cs}=$ metal concentration $(\mathrm{mg} / \mathrm{kg})$

$\mathrm{F}_{\text {(route })}=$ Bioavailability, i.e., absorbed fraction of the ingested metals

$\mathrm{IR}=$ dust ingestion rate ( $\mathrm{mg}$ solid/day)

$\mathrm{CF}=$ Conversion factor $(10 \mathrm{E}-6 \mathrm{~kg} / \mathrm{mg})$

$\mathrm{EF}=$ exposure frequency (days/year)

$\mathrm{ED}=$ exposure duration (years)

$\mathrm{BW}=$ bodyweight $(\mathrm{kg})$

$\mathrm{AT}=$ averaging time (days)

$\operatorname{InhR}=$ Inhalation rate $\left(\mathrm{m}^{3} /\right.$ day $)$

$\mathrm{PEF}=$ Particulate emission factor $\left(\mathrm{m}^{3} / \mathrm{kg}\right)$

$\mathrm{VF}=$ Volatilization factor $\left(\mathrm{m}^{3} / \mathrm{kg}\right)$

$\mathrm{ABS}=$ Dermal bioavailability

$\mathrm{SA}=$ Skin surface area available for contact $\left(\mathrm{cm}^{2} /\right.$ event $)$ 
$\mathrm{AF}=$ Soil to skin adherence factor $\left(\mathrm{mg} / \mathrm{cm}^{2}\right)$

The risk assessments of each element were evaluated by incorporating RBA calculated into exposure and hazard quotient (HQ) was determined for carcinogenic and non-carcinogenic effects using Equations (4) and (5). The HI was calculated as the sum of HQs from the different pathways (Equation 7).

Hazard Quotient $(H Q)$ Risk (non-cancer) $=$ Exposure $=\underline{D \times R B A} \quad \ldots \ldots \ldots \ldots(7)^{37}$ Safe Dose $\quad$ Rf $D$

Meanwhile, Hazard Quotient $(H Q)$ Risk (Cancer) $=$ Exposure $\mathrm{x}$ Cancer Slope Factor (8)

$\mathrm{HI}=\Sigma \mathrm{HQ}=\mathrm{HQ}_{\text {ing }}+\mathrm{HQ}_{\text {inh }}+\mathrm{HQ}_{\text {derm }}$

Where:

"Safe Dose" is based on threshold for toxicity, including uncertainty factor (e.g., Reference dose or "RfD") i.e. $\mathrm{RfD}_{\mathrm{ad}} \mathrm{RfD}_{\mathrm{i}}, \mathrm{RfD}_{\mathrm{o}}$ are absorbed chronic reference dose, Inhalation chronic reference dose, and Oral chronic reference dose respectively in $\mathrm{mg} / \mathrm{kg}$-day (they are metal specific)

\section{Data Analysis}

The "Analysis Toolbar" available in Microsoft Office of Excel 2007 and SPSS version 14 software's provided data analysis. Non-parametric statistical methods were used to evaluate whether there is a significant differences between concentrations of metals at different sampling times at each sampling site. Data obtained were also subjected to analysis of variance (ANOVA) to enable us assess the levels of significant difference.

\section{Results and Discussion}

\section{Particles Size Distribution}

The main focus of this study is to confirm that metals bound to dust of different particle sizes possess different uptake and varied human health risk. We hypothesized that elevated concentrations of metal bound to different particle sizes of dust do not necessarily result in high bioavailability. Firstly, metals load in dust could increase with increasing particle sizes; if this hypothesis is correct, the metals on particle surface might decrease steadily with particle size, else the coarse particles are more loaded than fine particles. Secondly, metals bounds to different particle sizes could be exist in different chemical forms; if this is true, bioavailability increases with decreasing particle sizes. In contrast, their bioavailability would depend on physicochemical properties

To test our hypothesis, we measured the mass load and particle size distribution in microns $(<10$ $\mu, 10-50 \mu$, and $>50 \mu$ ) at various sites of our study centre. The total mass load of dust samples (Table 2) show significant $(\mathrm{p}<0.05)$ spatial variation among the sites; according to the land uses. The order of variation shows commercial $>$ traffic $>$ residential $>$ government reserved area. This order agreed with the trends observation in other cities [39]. In all sites, the annual time- 
weighted mean of fine particulate matters in our study is less than $50 \mathrm{gm}^{-3}$ stipulated by USEPA [40].

In addition, it can be found that particle size distribution (Table 3$)$ shows that $(>50 \mu \mathrm{m})$ sizes dominate in all the sampled sites, except the traffic impacted site. This is an indication that fresh sources are impacting the environments. The larger coarse particles (i.e., greater than $10 \mu \mathrm{m}$ ) tend to rapidly fall out of the air and have atmospheric lifetimes on the order of minutes to hours, depending on their size and other factors [41].

The results of physic-chemical characteristic of dust (Table 3) showed that $\mathrm{pH}$ values ranged between 6.9 and 9.4 in all the sampling sites, while the organic matter content showed values in range of 6.7 to $31.23 \%$. These parameters fall within values for typical urban soil. Further to these, the cation exchange capacity (CEC) varied from 31.74 to $43.4 \mathrm{cmol} / \mathrm{kg}$. The low conductivity could be due to geochemical nature of the environment and might reduce the metals bioavailability [42].

We investigated the mineralogical composition analysis of the samples, to identify major metals species in dust samples. Table 4 present the results of the average atomic weight percent of different elements in the samples. The results show that the dust particles contain majorly silica $\left(\mathrm{SiO}_{2}\right)$ and alumina $\left(\mathrm{Al}_{2} \mathrm{O}_{3}\right)$. Although, oxides of $\mathrm{Mn}$, and $\mathrm{Fe}$ were also present, with $\mathrm{Si}$ being the most abundant.

\section{Metals Distribution in Dust particles}

The mean metals distribution (Table 5) in this study showed that $\mathrm{Zn}(462.1 \mu \mathrm{g} / \mathrm{g}), \mathrm{Mn}(301.09$ $\mu \mathrm{g} / \mathrm{g}), \mathrm{Ni}(215.48 \mu \mathrm{g} / \mathrm{g}), \mathrm{Fe}(313.26 \mu \mathrm{g} / \mathrm{g}), \mathrm{Pb}(88.2 \mu \mathrm{g} / \mathrm{g}), \mathrm{Cu}(28.17 \mu \mathrm{g} / \mathrm{g}), \mathrm{Cd}(10.64 \mu \mathrm{g} / \mathrm{g})$ and $\operatorname{Cr}(5.1 \mu \mathrm{g} / \mathrm{g})$. The high concentrations of $\mathrm{Zn}$ and $\mathrm{Pb}$, in studied sites of this work, are not surprising as both metals are from vehicular emission. $\mathrm{Zn}$ has the ability to occlude within the crystal lattice layer of silicate. Activities of welder are considered a major significant source of $\mathrm{Ni}$ and $\mathrm{Mn}$ to the urban pollution load. Welding fumes are solid particles that originated from the base metals/electrode coatings, and the vaporized metal condenses into tiny particles.

Meanwhile, on comparison of the mean metals concentration in this study with other cities, it was observed that the mean values of our study were significantly lower than others. This may be attributed to difference in traffic volume.

The distributions of these metals in different particle sizes were also investigated and presented in Figures 1. It is evident from the results that the smallest particles, $<10 \mu \mathrm{m}$, had metal concentrations ( $\mu \mathrm{g} / \mathrm{g})$ as follows: $\mathrm{Pb}(3.02 \mu \mathrm{g} / \mathrm{g}), \mathrm{Zn}(2.4 \mu \mathrm{g} / \mathrm{g}), \mathrm{Cu}(2.1 \mu \mathrm{g} / \mathrm{g}), \mathrm{Cd}(0.03 \mu \mathrm{g} / \mathrm{g})$, $\mathrm{Ni}, \mathrm{Mn}$. In particle sizes of $10-50 \mu \mathrm{m}$ and $>50 \mu \mathrm{m}$, concentrations of $\mathrm{Cd}$ in the all the fractions were nearly independent of the particle size of the dusts, as each fraction contained a certain amount in each size. However, concentrations of $\mathrm{Zn}$ and $\mathrm{Pb}$ showed steady decrease with increasing particle sizes. The observed trend in $\mathrm{Zn}$ and $\mathrm{Pb}$ may be attributed to decrease in available surface area with increase particle sizes. This is not surprising, as chemical reactivity is expected to be lower in coarse particles due to large surface area of smaller particles. However, the spatial variations in these metals distribution may be attributed to difference in traffic speed in the area.

Metals such as $\mathrm{Cd}$, and $\mathrm{Pb}$ are generally found in airborne compounds with a single predominate oxidation state $\mathrm{Cd}$ (II), $\mathrm{Pb}(\mathrm{II})$ ). Some metals (e.g., the transition metals $\mathrm{Cr}$, $\mathrm{Mn}$, and $\mathrm{Ni}$ ) present the possibility of changing oxidation state in situ in the particle, although little is known of these processes [47]. This is an important consideration for health risk assessment as the different oxidation states also differ in toxicity, Overall, the distributions of metals in different particle sizes 
fractions of dust of Akure showed that particles fraction with size $>50 \mu \mathrm{m}$ contain more metals than the fine particles. The above observations confirm our first proposed hypothesis.

\section{Speciation of Metals}

We investigated the speciation patterns of metals in dust particles at different geochemical phases and the results of our study are depicted in Figure 2. Some of the striking features of this figure are highlighted as follows; Firstly, in all the particle sizes, $\mathrm{Pb}$ is associated and different distributed in various geochemical phases. We interpret this as indicating that multiple $\mathrm{Pb}$ species, including $\mathrm{Pb}$ carbonate, $\mathrm{Pb}$ humate, $\mathrm{Pb}$ absorbed into $\mathrm{Fe}$ oxide, $\mathrm{Pb}$ metal, $\mathrm{PbO}, \mathrm{Pb}$ hydroxyl carbonate. Yang et al [49] also reported a similar pattern of $\mathrm{Pb}$ speciation while describing its absorption on $\beta-\mathrm{MnO}_{2}$. These compounds are used as white paint pigments. Secondly, in particle of $<10 \mathrm{~mm}$, Ni predominates in the residual fraction. Meanwhile, $\mathrm{Zn}$ had their highest contents in carbonate fraction, which may be attributed to high dust $\mathrm{pH}$. The decreasing order of these elements in geochemical fractions is shown as; Carbonate $>$ Reducible $>$ Residual $>$ Exchangeable $>$ Oxidisable. However, $\mathrm{Cd}$ dominates the exchangeable and carbonate fractions. This observation was earlier attributed to the metal affinity [48]. Thirdly, in particles of $>50 \mu \mathrm{m}, \mathrm{Mn}$ and $\mathrm{Fe}$ had their highest concentration in residual fraction. The association pattern of iron in the different phases were in the order Residual $>$ Reducible $>$ Oxidizable $>$ Exchangeable $>$ Carbonate. Overall, $\mathrm{Zn}$ had the highest total metal concentrations, but most of the $\mathrm{Zn}$ was bound to residual fraction that was unavailable to human being.

\section{Metals Bioavailability}

To verify the hypothesis that elevated concentrations of metals in dust samples do not necessarily result in high bioavailability. We determined the relative bioavailability of the various metals using two-step physiological extraction (PBET). The measured solubility or release metal expressed as amount of metal per amount of metal loaded is presented in Figure 4. The bioavailability of the metals shows the order $\mathrm{Cd}>\mathrm{Zn}>\mathrm{Pb}>\mathrm{Ni}>\mathrm{Cu}$. One striking feature of this result is that Cadmium consistently had highest relative bioavailable in all particle sizes in this study, despite its low concentration in dust particles. The bioavailable of $\mathrm{Cd}$ varied between $78.7 \%$ and $71.6 \%$ of the total concentration of $\mathrm{Cd}$ for $<10 \mu \mathrm{m}$ to $10-50 \mu \mathrm{m}$ particle sizes. This has been attributed to its existence in forms that range from sparingly or moderately to highly soluble; high affinity for exchangeable and carbonate fractions [47], hence it exhibits a wide range of bioavailability in soil. This may result in relatively high internal doses, and explains the large contribution made by cigarette smoking to the body burden of $\mathrm{Cd}$ [50]. Meanwhile, the relative bioaccessibility of $\mathrm{Cd}$ was closely followed by $\mathrm{Zn}$ and $\mathrm{Pb}$, with values ranged between $69.6 \%$ and $68.3 \%$ from particle size $<10 \mu \mathrm{m}, 65.09$ and 62.3 for $10-50 \mu \mathrm{m}$, and 65.06 and 60.3 $\mu \mathrm{m}$ for $>50$ (Figure 3). The observed bioavailability of these metals ( $\mathrm{Pb}$, and $\mathrm{Zn}$ ) appears to increase with decreasing particle sizes. However, the reverse trend was observed for $\mathrm{Mn}, \mathrm{Cu}, \mathrm{Ni}$ and $\mathrm{Fe}$ concentrations while the bioaccessibility of $\mathrm{Cr}$ showed no consistent trend. This was attributed largely to its existence in the differences in oxidation state of Chromium $\left(\mathrm{Cr}^{3+}\right.$ and 
$\mathrm{Cr}^{6+}$ ) and metal speciation [51, 52]. Although at present, there is no general means of predicting how the oxidation state of a particular element will affect toxicity. Further to these, metals like $\mathrm{Cu}, \mathrm{Mn}$, and $\mathrm{Fe}$ had high total concentration in dust but showed low bioaccessibility results. Overall, we observed that $\mathrm{Cd}$ was low in dust samples but their bioavailability was high. This observation goes to support the earlier hypothesis.

On comparison of mean bioaccessibility (\%) values of metals in our Centre with other cities of the world (Table 6), we observed significantly low values for metals such as $(\mathrm{Cd}, \mathrm{Ni})$, while high differences were observed in others. The difference in bioaccessibility may be attributed to difference in metal speciation between the cities.

\section{Relationship between relative bioavailability and physicochemical properties}

The relationship between physicochemical properties and bioavailability is crucial, when linking exposure concentrations and estimates in vitro bioaccessibility in ecotoxicology studies. We attempted to obtain equations that can be used to estimate the bioaccessibility, as measured in the in vitro bioaccessibility assay (IVBA) to physicochemical properties. It was assumed that Conductivity and organic matter could contribute to difference in bioavailability of metals in dust. The stepwise multiple regression models were used to study possible correlation. Table 7 presents the regression equations for metals studied in this work.

From the results, we found that $\mathrm{Ni}$ and $\mathrm{Cr}$ differently, exhibited a slightly positive correlation with $\mathrm{R}^{2}=0.390$ and $\mathrm{R}^{2}=0.356$ respectively. In both of them, organic carbon (OM) was found to have no significant correlation with its bioaccessibility. However, for $\mathrm{Pb}$, there was negative correlation between metal bioavailability and organic matter, and positive correlation exists between bioaccessibility and soil pH. Similarly, there were no significant relationship between the total metals and soil properties such as $\mathrm{pH}$ and Organic matter. Furthermore, it was found that organic matter content and conductivity result in decrease metal bioaccessibility. Generally, it is reasonable to believe that some combination of physicochemical characteristics determine metal bioaccessibility within dust.

\section{Health risk Assessment.}

Table 8 presents the exposure to the various metals $(\mathrm{Cd}, \mathrm{Pb}, \mathrm{Zn}, \mathrm{Ni}, \mathrm{Cu}, \mathrm{Cr}, \mathrm{Fe}$ and $\mathrm{Mn})$ bound dusts, cancer and non-cancer risks in humans for both adult and children scenarios via inhalation, ingestion and dermal contact exposure pathways. We calculated these values for particle size $<10 \mathrm{~mm}$ only, due to the fact that the lowest particle has potential to penetrate to the lung more than other sizes. From the results, we observed that total exposure HI from ingestion, dermal and inhalation for $\mathrm{Cd}$ and $\mathrm{Pb}$ were higher for children than adults. The HI values observed for both children and adults decrease in the order $\mathrm{Cd}>\mathrm{Cu}>\mathrm{Pb}>\mathrm{Fe}>\mathrm{Zn}$.

Generally, the observed inhalation cancer risks for metals were very high when compared to other exposure routes (ingestion and dermal contact). This may be attributed to the fact that ultrafine particles can penetrate deeply into the lungs and cause adverse health effects.

Conclusions: The results of this study revealed that some combination of physicochemical characteristic determines metals bioaccessibility within dust particle sizes. The distribution of metals in particle sizes showed that coarse particles contain more metals than fine particles. Meanwhile, metals in the dust samples collected in this study exist mostly in non-mobile fraction. We confirmed that the threat posed by metals associated with airborne particulates depends upon their associated fraction rather than total concentration. The observed inhalation 
cancer risks for metals were very high when compared to other exposure routes (ingestion and dermal contact). We hope the report will be of interest to environmentalist, health policy makers, stimulate environmental concerns and translate into improved respiratory health among inhabitants.

\section{References}

1. ISO. Air Quality - Particle Size Fraction Definitions for Health-related Sampling ISO Standard 7708 International Organization for Standardization (ISO), Geneva. (1995)

2. Peter, S.Y.; Thomason, E.; Krombout, H. Personal Exposure to Inhalable Cement dust among Construction workers. J. Environ. Monitoring. 2009, 11 (1), 174 - 180

3. TUC. Dust in the Workplace Health and safety, 2011.

4. Carda, V.; Reyes, L.M.; Barbasa, J.M.; Elizondo-Martunez, P.; Acumanshar, K. Contamination and Chemical fractionation of heavy metals in street dust from the Metropolitan Area of Monterrey, Mexico. Environ. Technology. 2011, 32 (10), 1163 1172.

5. Salmanzadeh, M.; Saeedi, M.; Li, L.Y.; Nabi-Bidhendi, Gh.. Characterization and metal fractionation of street dust samples from Tehran, Iran. International Journal of Environmental Research. 2015, 9 (1), 213 - 224.

6. Shinggu, D.Y.; Ogugbuaja, V.O.; Barminas, J.T.; Toma T. Analysis of street dust for heavy metal pollution in Mubi, Adamawa state, Nigeria. International Journal of Physical Sciences. 2007, 2, 290 - 293.

7. Ogunfowokan, A.O.; Oyekunle, J.A.O.; Durosinmi, L.M.; Akinjokun, A.I.; Gabriel, O.D. Speciation Study of Lead and Manganese in roadside dust from major roads in Ile Ife South Western Nigeria. Chemistry and Ecology, 2009, 25(6), 405 - 415.

8. Okunola, O.J.; Uzairu, A.; Uba, S.; Ezeanyanaso, C.S.; Al Hassan, Y. Distribution Pattern of Metals in Atmospheric Settling Dust along Roads in Kano Metropolis, Nigeria. Jour. of App. Chem. 2015; Article ID 739325, 12Pages

9. Mafuyai, G.M.; Eneji, I.S.; Sha'Ato, R. Concentration of Heavy Metals in respiratory Dust in Jos Metropolitan Area, Nigeria. Open Journal of Air Pollution 2014, 3, 10 -19 http://dx.doi.org/10.4236/ajop.2014.31002.

10. Dimari, G.A.; Abudlrahaman, F.J.; Akan, J.C.; Ogugbuaja, V.O. Elemental and some anion concentration of Total Suspended Matter in Relation to Air Pollution in Maiduguri, Borno State, Nigeria. Research Journal of Environmental Toxicology 2008, 2, 9 - 16 DOI: 103923/rejet.2008.9.16

11. Hoek, G.; Brunekreef, B.; Goldbohm, S.; Fischr, P.; Brandt, P.A.; van den Association between mortality and indicators of traffic-related air pollutionin the Netherlands: a cohort study, Lancet. 2002, 360, 1203 - 1209.

12. Pope III, C. A.; Burnett, R. T.; Thun, M. J.; Calle, E. E.; Krewski, D.; Ito, K..; Thruston, G. D. Lung cancer, cardiopulmonary mortality, and long-term exposure to fine particulate air pollution. J. Am. Med. Assoc., 2002, 287, 1132-1141.

13. Mills, N.L.; Donaldson, k.; Hadoke, P.W.; Boon, N.A.; MacNee, W.; Cassee, F.R.; Sandstrom, T.; Blomberg, A.; Newby, D.E. Adverse cardiovascular effects of air pollution. Nat.Clin. Pract. Card. 2009, 6, $36-44$.

14. Guo, G.; Yolan, T.; Wang W et al. Effect of aging on bioavailability of copper on the fluvo aquic soil. Intern. Journ. Of Environ. Sci. Techn. 2011, 8: 715 - 722 
15. Ruby, M.V.; Davis, A.; Schoof, R.; Eberle, S.; Sellstone, C. Estimation of lead and arsenic bioavailability using a physiologically based extraction test. Environ. Sci. Techn. 1996, 30(2), 422-430

16. Ruby, M.V.; Lowney, Y.W.; Bunge, A.L.; Roberts, S.M.; Gomez-Eyles, J.L.; Ghosh, U.; Kissel, J.C.; Tomlin-son, P.; Menzie C. Oral Bioavailability, Bioaccessibility, and Dermal Absorption of PAHs from Soil-State of the Science. Environ. Sci. Technol., 2016, 50, 2151-2164

17. Allen, E. Standards for metals should not be based on total concentrations, SETAC Europe News. 1997, 8, 7.

18. Kelley, M.E.; Brauning, S.E.; Schoof, R. A et al. Assessing oral bioavailability of metals in soil. Battelle Press, Columbus, $\mathrm{OH}$, 2002, www.battelle.org/bookstore.

19. Collins, C.D.; Craggs, M.; Garcia-Alcega, S.; Kademoglou, K.; Lowe, S. Towards a unified approach for the determination of the bioaccessibility of organic pollutants. Environment International 2015, 78, 24-31.

20. Salvador, P.; Arttnano, B.; Alonso, D.G.; Querol, X.; Wate, S.RIdentification and characterization of sources of PM10 in Madrid (Spain) by statistical methods. Atmos. Environ. 2002, 38,435 - 447.

21. Luo, X.S.; Yu, S.; Li, X.D. Distribution, availability, and sources of trace metals in different particle size fractions of urban soils in Hong Kong: implications for assessing the risk to human health. Environ Pollut. 2011, 159:1317-26.

22. Okorie, A.; Entwistle, J.; Dean, J.R. The application of in vitro gastrointestinal extraction to assess oral bioaccessibility of potentially toxic elements from an urban recreational site. Appl. Geochem. 2011, 26:789-96.

23. Oomen, A.G.; Hack, A.; Minekus, M.; Zeijdner, E.; Cornelis, C.; Schoeters, G, et al. Comparison of five in vitro digestion models to study the bioaccessibility of soil contaminants. Environ Sci Technol. 2002, 36, 3326-34.

24. Basta M.; Gradwohl R. Estimation of $\mathrm{Cd}, \mathrm{Pb}$, and $\mathrm{Zn}$ bioavailability in smelter contaminated soils by sequential extraction procedure. J. Soil. Contam. 2000, 9: 149164.

25. Cui , X.; Xiang, P.; He, R.; Juhasz, A.; Ma, L. Advances in in vitro methods to evaluate oral bioaccessibility of PAHs and PBDEs in environmental matrices Chemosphere. 2016, $150,378-389$.

26. Luo, X.-san.; Yu, S.; Li, X.-dong. The mobility, bioavailability, and human bioaccessibility of trace metals in urban soils of Hong Kong. Applied Geochemistry, 2012, 27(5), 995-1004.

27. Denys, S.; Caboche, J.; Tack, K.; Rychen, G.; Wragg, J.; Cave, M.; Jondreville, C.; Feidt, CIn Vivo Validation of the Unified BARGE Method to Assess the Bioaccessibility of Arsenic, Anti-mony, Cadmium, and Lead in Soils. Environ. Sci. Technol. 2012, 46 (11), 6252-6260.

28. Bradham, K.D.; Nelson, C.; Juhasz, A.L.; Smith, E.; Scheckel, K.; Obenour, D.R.; Miller, B.W.; Thomas, D.J. Independent Data Validation of an in Vitro Method for the Prediction of the Relative Bioa-vailability of Arsenic in Contaminated Soils. Environ. Sci. Technol. 2015, 49, 6312-6318.

29. Bradham, K.D.; Scheckel, K.G.; Nelson, C.M.; Seales, P. E.; Lee, G.E.; Hughes, M.F.; Miller, B.W.; Yeow, A.; Gilmore, T.; Harper, S.; Thomas, D.J. Relative bioavailability 
and bioaccessibility and speciation of arsenic in contaminated soils. Environ. Health Perspect. 2011, 119(11), 1629-1634.

30. Freeman, G.B.; Johnson, J.D.; Killinger, J.M.; Liao, S.C.; Davis, A.O.; Ruby, M.V.; Chaney, R.L.; Lovre, S.C.; Bergstrom, P.D. Bioavailability of arsenic in soil impacted by smelter activities following oral administration in rabbits. Fundam Appl Toxicol. 1993, 21(1), 83B88.32.

31. Nigeria census final results, Official Gazette, National Population Commission (NPC), Federal Republic of Nigeria, 2009.

32. Odjugo, P.A.O. Regional evidence of Climate Change in Nigeria, J. Geographical Regional Planning., 2010, 3(6), $142-150$

33. Yu, B.; Wang, Y.; Zhou, Q. Human Health Risk Assessment Based on Toxicity Characteristic Leaching Procedure and Simple Bioaccessibility Extraction Test of Toxic Metals in Urban Street Dust of Tianjin, China. PLos ONE. 2014, 9(3):e92459.doi:10.1371/journal.pone.0092459

34. Besombes, J.L.; Maitre, A.; Patissier, O.; Marchand. N.; Chevron, N.; Stoklov, M.; Masclet, P. Particulate PAHs observed in the surrounding of a municipal incinerator. Atmos. Environ. 2001, 35, 6093-6104.

35. Tessier, A; Campbell, PGC; Bisson, M. Sequential extraction procedure for the speciation of particulate trace metals. Anal Chem. 1979, 51(7):844B851.

36. U.S. EPA. Supplemental Guidance for Developing Soil Screening Levels for Superfund Sites. Document Number: OSWER 9355.4-24, March 2001. http://www.epa.gov/superfund/health/conmedia/soil/pdfs/ssg_main.pdf

37. USEPA, Methods for Derivation of Inhalation Reference Concentrations and Application of Inhalation Dosimetery. Environmental Criteria and Assessment, Office Of Health and Environmental and assessment, Office Of Research and Development, USEPA Research Triangle Park, North Caroline EPA/600/8-90/066F.1994

38. Byczkowski, J.Z. Application of bioavailability in assessment of human health hazards: Technical Decision Compendium, Ohio EPA Division of Environmental Response and Revitalization, Assessment, Clean up and Reuse Section, Response Program, 2002

39. Lau, S.L.; Stenstron, M.K. Metal and PAHs adsorbed to street particles. Water Researcher. (2005), 39, 4083 - 4092

40. SNIFFER (Scotland and Northern Ireland Forum for Environmental Research). $\mathrm{PM}_{2.5}$ in the UK. Published 2010 onlinehttp://www.sniffer.org.uk

41. Ellis, D.R.; Salt, D.E.; Plants, selenium and human health. Curr. Opin. Plant Biol. 2003, 6, 273-279.

42. Shuman, L. Effects of organic waste amendment on $\mathrm{Zn}$ adsorption by two soils. Soil Science. 1999,164,197.

43. Charlesworth, S.M; Everett, R.; McCarthy, R.; Ordonez, A.; De-Miguel, E. A comparative study of heavy metal concentration and distribution in deposited street dusts in a large and a small urban area: Birmingham and Coventry, West Millands, UK. Environment International. 2003, 29, 563 - 573.

44. Li, X.; Poon, C.S.; Liu, PS. Heavy metal contamination of urban soils and Street dusts in Hong Kong. Applied Geochemistry 2001, 16, 1361 - 1368.

45. Han, L.S.; Wuang, Z.; Cheng, S.; Wang, Y.; Li J. Characteristics of resuspended road dust and its impact on the atmospheric environment in Beijing. Atmospheric Environment 2007; $41: 7485-7499$ 
46. Luo, X..; Ding, J.; Xu, B.; Wang, Y.; Li, H.; Yu, S. Incorporating bioaccessibility into human health risk assessments of heavy metals in urban park soils. The Science of the Total Environment. 2012, 424, 88. doi:10.1016/j.scitotenv.2012.02.053

47. Ljung, K..; Oomen, A.; Duits, M.; Selinus, O.;Berglund, M. Bioaccessibility of metals in urban playground soils. Journal of Environmental Science and Health. Part A, Toxic/hazardous substances \& environmental engineering. 2007, 42(9), 1241-50. doi:10.1080/10934520701435684

48. Yang, J.K.; Barnett, M.O.; Jardine, P.M.; Basta, N.T.; Casteel, S.W. Adsorption, Sequestration, and bioaccessibility of As(V) in soil. Environ. Sci. Technol. 2002, 36(21), $4562-4569$.

49. Li, T.; Wang, Y.; Li, W.J.; Chen, J.M.; Wang, T.; Wang, W.X. Concentration and Solubility of trace metals in fine particles at a mountain site, South China: Regional Source and Processing. Atmospheric Chemistry and Physics. 2015, 15, 8979 - 9002

50. Banerjee, A.D.K Heavy metal levels and solid phase speciation in street dust of Delhi, India Environmental Pollution. 2003, 123, 95-105

51. Barnhart, J. Chromium chemistry and implications for environmental fate and toxicity. J Soil Contam. 1997, 6(6), 561-568.

52. James, B. R.; Petura, J.C.; Vitale, R.J.; Mussoline, G. R. Oxidation-reduction chemistry of chromium: Relevance to the regulation and remediation of chromate-contaminated soils. Soil Contam. 1997, 6(6):569-580 
Table 1 Description of the monitoring locations, their Characteristics and Co- ordinates at Akure

\begin{tabular}{|c|c|c|c|}
\hline & $\begin{array}{l}\text { Site } \\
\text { Code }\end{array}$ & Coordinate & Description \\
\hline 1 & AKEX & 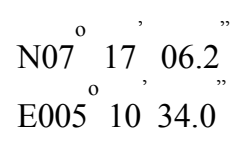 & $\begin{array}{l}\text { Created along Ilesa- Akure- Owo/Benin road, an express way } \\
\text { and close to the NNPC station. }\end{array}$ \\
\hline 2 & AKOA & 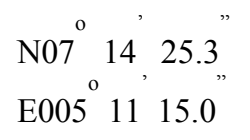 & $\begin{array}{l}\text { Oke - Aro monitoring site, a residential area with many local } \\
\text { buildings and close to furniture workshops. }\end{array}$ \\
\hline 3 & AKOB & $\begin{array}{l}\text { N07 }{ }^{\circ} 15^{\prime}, 12.7^{\prime \prime} \\
\text { E005 } 1143.8\end{array}$ & Created at the Oja Oba, a market square with heavy traffic. \\
\hline 4 & AKAL & 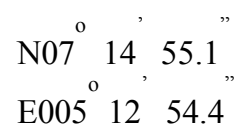 & Alagbaka monitoring site, the site of many government offices. \\
\hline 5 & AKOR & $\begin{array}{l}\text { N07 }{ }^{\circ} 49,47.2^{\prime \prime} \\
\text { E005 } 0937.9\end{array}$ & $\begin{array}{l}\text { Ondo road park monitoring site, a bus terminus with a cluster } \\
\text { of petrol dispensing stations. }\end{array}$ \\
\hline 6 & AKBR & 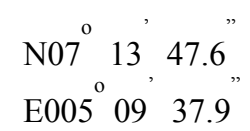 & $\begin{array}{l}\text { Aponmu monitoring site, a small community and a background } \\
\text { site for the study. }\end{array}$ \\
\hline
\end{tabular}

Table 2: The chemical composition of Gamble's solution

\begin{tabular}{|l|l|}
\hline Chemical & Concentration (in g/L) \\
\hline $\mathrm{MgCl}_{2}$ & 0.0953 \\
\hline $\mathrm{NaCl}$ & 6.0193 \\
\hline $\mathrm{KCl}$ & 0.2982 \\
\hline $\mathrm{NaHPO}_{4}$ & 0.126 \\
\hline $\mathrm{NaSO}_{4}$ & 0.063 \\
\hline $\mathrm{CaCl}_{2} 2 \mathrm{H}_{2} \mathrm{O}$ & 0.3676 \\
\hline $\mathrm{C}_{2} \mathrm{H}_{3} \mathrm{O}_{2} \mathrm{Na}_{2} \mathrm{H}_{2} \mathrm{O}$ (Sodium acetate ) & 0.7005 \\
\hline $\mathrm{C}_{6} \mathrm{H}_{5} \mathrm{Na}_{3} \mathrm{O}_{7} .2 \mathrm{H}_{2} \mathrm{O}$ (Sodium citrate) & 0.097 \\
\hline $\mathrm{NaHCO}_{3}$ & 2.6043 \\
\hline
\end{tabular}

Table 3: Particle Count and some physicochemical properties of the dust samples

\begin{tabular}{|l|l|l|l|l|l|l|}
\hline Site & $\begin{array}{l}\text { Total Mass } \\
\text { (Particle count) }\end{array}$ & $\begin{array}{l}\text { Percent of } \\
\text { particle } \\
<10 \mathrm{~mm}\end{array}$ & $\mathrm{pH}$ range & $\begin{array}{l}\text { Organic } \\
\text { matter } \\
\text { content }(\%)\end{array}$ & $\begin{array}{l}\text { CEC } \\
(\mathrm{cmol} / \mathrm{kg})\end{array}$ & $\begin{array}{l}\text { Conductivity } \\
(\mu \mathrm{Scm}-1)\end{array}$ \\
\hline AKEX & $1421.31 \pm 121.6$ & $24.2 \pm 9.6$ & $7.7-9.0$ & $10.7 \pm 3.5$ & $43.79 \pm 3.2$ & $84.1 \pm 6.2$ \\
\hline AKOB & $1541.99 \pm 104.4$ & $32.0 \pm 6.7$ & $7.5-9.1$ & $8.3 \pm 2.7$ & $33.03 \pm 3.3$ & $103.2 \pm 14.7$ \\
\hline
\end{tabular}




\begin{tabular}{|l|l|l|l|l|l|l|}
\hline AKOR & $1613.28 \pm 181.9$ & $30.6 \pm 8.5$ & $7.8-9.3$ & $12.8 \pm 4.1$ & $42.86 \pm 4.8$ & $92.6 \pm 8.0$ \\
\hline AKAL & $1511.83 \pm 150.4$ & $29.1 \pm 9.2$ & $7.2-9.4$ & $16.2 \pm 5.4$ & $31.74 \pm 2.1$ & $87.1 \pm 6.5$ \\
\hline AKOK & $1185.03 \pm 173.8$ & $23.8 \pm 8.8$ & $7.5-9.4$ & $10.5 \pm 3.9$ & $38.09 \pm 4.0$ & $90.7 \pm 3.8$ \\
\hline $\begin{array}{l}\text { Background } \\
\text { site }\end{array}$ & $1162.26 \pm 203.5$ & $12 \pm 3.9$ & $6.9-7.9$ & $23.7 \pm 8.4$ & $15.09 \pm 3.9$ & $70.9 \pm 2.7$ \\
\hline
\end{tabular}

Table 4: The Average atomic weight percent fraction of different elements in dust samples of Akure

\begin{tabular}{|l|l|l|l|l|l|l|}
\hline \multirow{2}{*}{ Sites } & Atomic percent & $\% \mathrm{Al}$ & $\% \mathrm{Mg}$ & $\% \mathrm{Ca}$ & $\% \mathrm{Na}$ & $\% \mathrm{Fe}$ \\
\cline { 2 - 7 } & $\% \mathrm{Si}$ & $\% \mathrm{Al}$ & 3 & 4 & 5 & 8 \\
\hline AKEX & 59 & 15 & 2 & 4 & 5 & 10 \\
\hline AKOB & 63 & 13 & 2 & 8 & 5 & 10 \\
\hline AKOR & 51 & 15 & 3 & 6 & 5 & 6 \\
\hline AKAL & 60 & 14 & 3 & 6 & 5 & 6 \\
\hline AKOK & 52 & 12 & 3 & 4 & 5 & 4 \\
\hline $\begin{array}{l}\text { Background } \\
\text { site }\end{array}$ & 67 & 9 & 3 & & & \\
\hline
\end{tabular}

Table 5: Comparisons of heavy metal content $\left(\mu \mathrm{gg}^{-1}\right)$ in street dust in this study with other cities of the world

\begin{tabular}{|l|l|l|l|l|l|l|l|l|l|}
\hline city & $\mathrm{Zn}$ & $\mathrm{Pb}$ & $\mathrm{Fe}$ & $\mathrm{Cu}$ & $\mathrm{Cr}$ & $\mathrm{Ni}$ & $\mathrm{Cd}$ & $\mathrm{Mn}$ & Reference \\
\hline $\begin{array}{l}\text { Akure, } \\
\text { Nigeria }\end{array}$ & 462.1 & 88.2 & 313.26 & 28.17 & 5.1 & 215.48 & 10.64 & 301.09 & This study \\
\hline Aviles, & 4829 & 514 & 4220 & 183 & 41.6 & $\mathrm{NA}$ & 22.3 & $\mathrm{NA}$ & {$[43]$} \\
\hline $\begin{array}{l}\text { Kuala } \\
\text { Lumpur }\end{array}$ & 344 & 2466 & 1790 & 35.5 & $\mathrm{Na}$ & $\mathrm{NA}$ & 2.93 & $\mathrm{NA}$ & {$[44]$} \\
\hline London & 680 & 1030 & 26000 & 155 & $\mathrm{Na}$ & $\mathrm{NA}$ & 3.5 & $\mathrm{NA}$ & {$[45]$} \\
\hline Ottawa & 184 & 68 & 25660 & 188 & 59 & NA & 0.6 & NA & {$[46]$} \\
\hline Seoul & 296 & 245 & $\mathrm{NA}$ & 101 & $\mathrm{Na}$ & NA & 3 & NA & {$[47]$} \\
\hline
\end{tabular}

Table 6: Comparison of mean metals bioaccessibility in Akure with other cities of the world.

\begin{tabular}{|l|l|l|l|l|l|l|l|l|l|}
\hline Cities & $\mathrm{Cd}$ & $\mathrm{Zn}$ & $\mathrm{Pb}$ & $\mathrm{Cu}$ & $\mathrm{Cr}$ & $\mathrm{Ni}$ & $\mathrm{Mn}$ & $\mathrm{Fe}$ & Reference \\
\hline $\begin{array}{l}\text { Akure, } \\
\text { Nigeria }\end{array}$ & $75.7 \pm 8.4$ & $43.0 \pm 14.2$ & $75.5 \pm 10.6$ & $65.4 \pm 15.8$ & \pm & $18.9 \pm 7.6$ & \pm & \pm & This study \\
\hline $\begin{array}{l}\text { Xiamen, } \\
\text { China }\end{array}$ & $\mathrm{NA}$ & 39 & 49 & 54 & $\mathrm{NA}$ & 26 & $\mathrm{NA}$ & $\mathrm{NA}$ & {$[46]$} \\
\hline $\begin{array}{l}\text { Uppsala, } \\
\text { Sweden }\end{array}$ & 26.3 & $\mathrm{NA}$ & 4.2 & $\mathrm{NA}$ & 4.2 & 3.9 & NA & NA & {$[47]$} \\
\hline $\begin{array}{l}\text { Toronto, } \\
\text { Canada }\end{array}$ & 75.5 & 43.0 & 75.5 & 65.4 & $\mathrm{NA}$ & 18.9 & NA & NA & \\
\hline
\end{tabular}

Table 7: Relationship between physicochemical properties and bioavailability (y)

\begin{tabular}{|l|l|l|}
\hline Metals & Equations & $\mathrm{R}^{2}$ \\
\hline $\mathrm{Cd}$ & $\mathrm{y}=1.041-0.699 \mathrm{pH}+0.342 \mathrm{OM}+0.039 \mathrm{CEC}+0.17 \mathrm{M}$ & 0.661 \\
\hline $\mathrm{Zn}$ & $\mathrm{y}=5.501-0.121 \mathrm{pH}+0.240 \mathrm{OM}+0.062 \mathrm{CEC}-0.22 \mathrm{M}$ & 0.538 \\
\hline $\mathrm{Pb}$ & $\mathrm{y}=6.399-0.447 \mathrm{pH}+2.015 \mathrm{OM}+0.009 \mathrm{CEC}-0.03 \mathrm{M}$ & 0.390 \\
\hline $\mathrm{Ni}$ & $\mathrm{y}=1.399-0.217 \mathrm{pH}+1.811 \mathrm{OM}+0.266 \mathrm{CEC}+0.63 \mathrm{M}$ & 0.704 \\
\hline
\end{tabular}




\begin{tabular}{|l|l|l|}
\hline $\mathrm{Cu}$ & $\mathrm{y}=4.018-0.039 \mathrm{pH}+0.0962 \mathrm{OM}+0.0511 \mathrm{CEC}+0.34 \mathrm{M}$ & 0.504 \\
\hline $\mathrm{Cr}$ & $\mathrm{y}=7.220-0.430 \mathrm{pH}+1.603 \mathrm{OM}+0.080 \mathrm{CEC}+0.80 \mathrm{M}$ & 0.356 \\
\hline $\mathrm{Mn}$ & $\mathrm{y}=2.270-0.30 \mathrm{pH}+1.116 \mathrm{OM}+0.009 \mathrm{CEC}-0.72 \mathrm{M}$ & 0.633 \\
\hline $\mathrm{Fe}$ & $\mathrm{y}=3.893-0.138 \mathrm{pH}+2.205 \mathrm{OM}+0.009 \mathrm{CEC}-0.20 \mathrm{M}$ & 0.384 \\
\hline
\end{tabular}

Table 8: Exposure to metals in dust via ingestion, dermal contact and inhalation for Adult and children at various sampled sites of Akure

\begin{tabular}{|c|c|c|c|c|c|c|c|c|c|c|c|c|}
\hline Metal & & $\mathrm{C}$ & Dinh & Ding & Dder & RfDih & RfDin & RfDder & Hih & Hin & Hder & HI \\
\hline \multirow[t]{2}{*}{$\mathbf{P b}$} & Child & 70.49 & $\begin{array}{l}1.295 E- \\
08\end{array}$ & 0.0004635 & $\begin{array}{l}\text { 1.41E- } \\
07\end{array}$ & \multirow{3}{*}{$\begin{array}{r}3.52 \mathrm{E}- \\
03 \\
3.52 \mathrm{E}- \\
03 \\
0.01\end{array}$} & $\begin{array}{l}3.50 \mathrm{E}- \\
03\end{array}$ & \multirow[t]{2}{*}{$5.25 \mathrm{E}-04$} & $3.678 \mathrm{E}-06$ & 0.1324274 & 0.0002685 & 0.1326996 \\
\hline & Adult & 70.49 & $\begin{array}{l}7.303 E- \\
08\end{array}$ & $4.966 \mathrm{E}-05$ & $\begin{array}{l}1.981 \mathrm{E}- \\
07\end{array}$ & & $\begin{array}{r}3.50 \mathrm{E}- \\
03\end{array}$ & & $2.075 E-05$ & 0.0141886 & 0.0003774 & 0.0145868 \\
\hline \multirow[t]{2}{*}{$\mathrm{Cr}$} & Child & 6.06 & $\begin{array}{l}1.113 E- \\
09\end{array}$ & $3.985 \mathrm{E}-05$ & $\begin{array}{l}1.212 \mathrm{E}- \\
08\end{array}$ & & 0.001 & $\begin{array}{l}5.25 E-04 \\
0.000025\end{array}$ & 1.113E-07 & 0.0398466 & 0.0004848 & 0.0403315 \\
\hline & Adult & 6.06 & $\begin{array}{l}\text { 6.278E- } \\
09\end{array}$ & $4.269 \mathrm{E}-06$ & $\begin{array}{l}1.703 E- \\
08\end{array}$ & - & $\begin{array}{l}1.00 \mathrm{E}- \\
01\end{array}$ & \multirow{2}{*}{$5.25 \mathrm{E}-04$} & \#VALUE! & $4.269 \mathrm{E}-05$ & $3.245 \mathrm{E}-05$ & \#VALUE！ \\
\hline \multirow[t]{2}{*}{$\mathbf{Z n}$} & Child & 65.54 & $\begin{array}{l}1.204 \mathrm{E}- \\
08\end{array}$ & $\mathbf{0 . 0 0 0 4 3 0 9}$ & $\begin{array}{l}1.311 \mathrm{E}- \\
07\end{array}$ & $\begin{array}{r}3.52 \mathrm{E}- \\
03\end{array}$ & $\begin{array}{l}3.50 \mathrm{E}- \\
03 \\
\end{array}$ & & $3.42 \mathrm{E}-06$ & 0.123128 & 0.0002497 & 0.1233811 \\
\hline & Adult & 65.54 & $\begin{array}{l}\text { 6.79E- } \\
08 \\
\end{array}$ & $4.617 \mathrm{E}-05$ & $\begin{array}{l}1.842 \mathrm{E}- \\
07\end{array}$ & $\begin{array}{r}3.52 \mathrm{E}- \\
03\end{array}$ & $\begin{array}{r}3.50 \mathrm{E}- \\
03\end{array}$ & $\begin{array}{l}5.25 \mathrm{E}-04 \\
6.00 \mathrm{E}-05\end{array}$ & $1.929 \mathrm{E}-05$ & 0.0131923 & 0.0030705 & 0.0162821 \\
\hline \multirow[t]{2}{*}{$\mathrm{Cr}$} & Child & 9.02 & $\begin{array}{l}1.657 \mathrm{E}- \\
09 \\
\end{array}$ & $5.931 \mathrm{E}-05$ & $\begin{array}{l}1.804 \mathrm{E}- \\
08 \\
\end{array}$ & $\begin{array}{l}2.86 \mathrm{E}- \\
05 \\
\end{array}$ & $\begin{array}{l}3.00 \mathrm{E}- \\
03\end{array}$ & $6.00 \mathrm{E}-05$ & 5.793E-05 & 0.0197699 & 0.0003007 & 0.0201285 \\
\hline & Adult & 9.02 & $\begin{array}{l}9.345 E- \\
09\end{array}$ & $6.355 \mathrm{E}-06$ & $\begin{array}{l}2.535 E- \\
08 \\
\end{array}$ & $\begin{array}{l}2.86 E- \\
05\end{array}$ & $\begin{array}{l}\text { 3.00E- } \\
03\end{array}$ & $6.00 \mathrm{E}-05$ & 0.0003267 & 0.0021182 & 0.0004226 & 0.0028675 \\
\hline \multirow[t]{3}{*}{ Cd } & Child & 6.44 & $\begin{array}{l}1.183 E- \\
09\end{array}$ & $4.235 \mathrm{E}-05$ & $\begin{array}{l}1.288 E- \\
08 \\
\end{array}$ & 0.01 & 0.001 & 0.000025 & 1.183E-07 & 0.0423452 & 0.0005152 & 0.0428605 \\
\hline & Adult & 6.44 & $\begin{array}{l}.672 E- \\
09 \\
\end{array}$ & $4.537 \mathrm{E}-06$ & $\begin{array}{l}1.81 \mathrm{E}- \\
08 \\
\end{array}$ & - & $\begin{array}{l}1.00 \mathrm{E}- \\
01\end{array}$ & $2.50 \mathrm{E}-05$ & \#VALUE! & $4.537 \mathrm{E}-05$ & 0.0007241 & \#VALUE! \\
\hline & Adult & 86.2 & $\begin{array}{l}8.931 E- \\
08\end{array}$ & $6.073 E-05$ & $\begin{array}{l}2.423 E- \\
07 \\
\end{array}$ & \multirow{2}{*}{$\begin{array}{l}3.52 \mathrm{E}- \\
03 \\
2.86 \mathrm{E}- \\
05\end{array}$} & $\begin{array}{r}3.50 \mathrm{E}- \\
03\end{array}$ & \multirow{2}{*}{$\begin{array}{l}5.25 \mathrm{E}-04 \\
6.00 \mathrm{E}-05\end{array}$} & $2.537 \mathrm{E}-05$ & 0.0173509 & 0.0004615 & 0.0178378 \\
\hline \multirow[t]{2}{*}{$\mathbf{N i}$} & Child & 9.92 & $\begin{array}{l}1.822 \mathrm{E}- \\
09\end{array}$ & $6.523 \mathrm{E}-05$ & $\begin{array}{l}1.984 \mathrm{E}- \\
08\end{array}$ & & $\begin{array}{l}3.00 \mathrm{E}- \\
03\end{array}$ & & $6.371 \mathrm{E}-05$ & 0.0217425 & 0.0003307 & 0.0221368 \\
\hline & Adult & 9.92 & $\begin{array}{l}1.028 E- \\
08\end{array}$ & $6.989 \mathrm{E}-06$ & $\begin{array}{l}2.788 E- \\
08\end{array}$ & $\begin{array}{l}2.86 \mathrm{E}- \\
05\end{array}$ & $\begin{array}{l}\text { 3.00E- } \\
03\end{array}$ & $6.00 \mathrm{E}-05$ & 0.0003594 & 0.0023295 & 0.0004647 & 0.0031536 \\
\hline \multirow[t]{3}{*}{$\mathrm{Cu}$} & Child & 8.21 & $\begin{array}{l}1.508 E- \\
09\end{array}$ & $5.398 \mathrm{E}-05$ & $\begin{array}{l}1.642 \mathrm{E}- \\
08\end{array}$ & 0.01 & 0.001 & 0.000025 & $1.508 \mathrm{E}-07$ & 0.0539836 & 0.0006568 & 0.0546405 \\
\hline & Adult & 8.21 & $\begin{array}{l}8.506 E- \\
09 \\
\end{array}$ & $5.784 \mathrm{E}-06$ & $\begin{array}{l}2.308 E- \\
08 \\
\end{array}$ & - & $\begin{array}{l}1.00 \mathrm{E}- \\
01\end{array}$ & $2.50 \mathrm{E}-05$ & \#VALUE! & $5.784 E-05$ & 0.0009231 & \#VALUE! \\
\hline & Adult & 51.82 & $\begin{array}{l}5.369 \mathrm{E}- \\
08\end{array}$ & $3.651 \mathrm{E}-05$ & $\begin{array}{l}1.457 \mathrm{E}- \\
07\end{array}$ & \multirow{2}{*}{$\begin{array}{l}3.52 \mathrm{E}- \\
03 \\
2.86 \mathrm{E}- \\
05\end{array}$} & $\begin{array}{r}3.50 \mathrm{E}- \\
03\end{array}$ & \multirow{2}{*}{$\begin{array}{l}5.25 \mathrm{E}-04 \\
6.00 \mathrm{E}-05\end{array}$} & $1.525 \mathrm{E}-05$ & 0.0104306 & 0.0002775 & 0.0107233 \\
\hline \multirow[t]{3}{*}{ Mn } & Child & 10.01 & $\begin{array}{l}1.839 \mathrm{E}- \\
09\end{array}$ & $6.582 \mathrm{E}-05$ & $\begin{array}{l}2.002 E- \\
08 \\
\end{array}$ & & $\begin{array}{l}3.00 \mathrm{E}- \\
03\end{array}$ & & $6.429 \mathrm{E}-05$ & 0.0219397 & 0.0003337 & $\mathbf{0 . 0 2 2 3 3 7 7}$ \\
\hline & Adult & 10.01 & $\begin{array}{l}1.037 \mathrm{E}- \\
08\end{array}$ & $7.052 \mathrm{E}-06$ & $\begin{array}{l}2.814 E- \\
08\end{array}$ & $\begin{array}{l}2.86 E- \\
05\end{array}$ & $\begin{array}{l}\text { 3.00E- } \\
03\end{array}$ & $6.00 \mathrm{E}-05$ & 0.0003626 & $\mathbf{0 . 0 0 2 3 5 0 7}$ & 0.000469 & 0.0031823 \\
\hline & Adult & 3.05 & $\begin{array}{l}3.16 E- \\
09\end{array}$ & $2.149 \mathrm{E}-06$ & $\begin{array}{l}8.573 E- \\
09\end{array}$ & - & $\begin{array}{l}1.00 \mathrm{E}- \\
01\end{array}$ & 2.50E-05 & \#VALUE! & 2.149E-05 & 0.0003429 & \#VALUE! \\
\hline
\end{tabular}




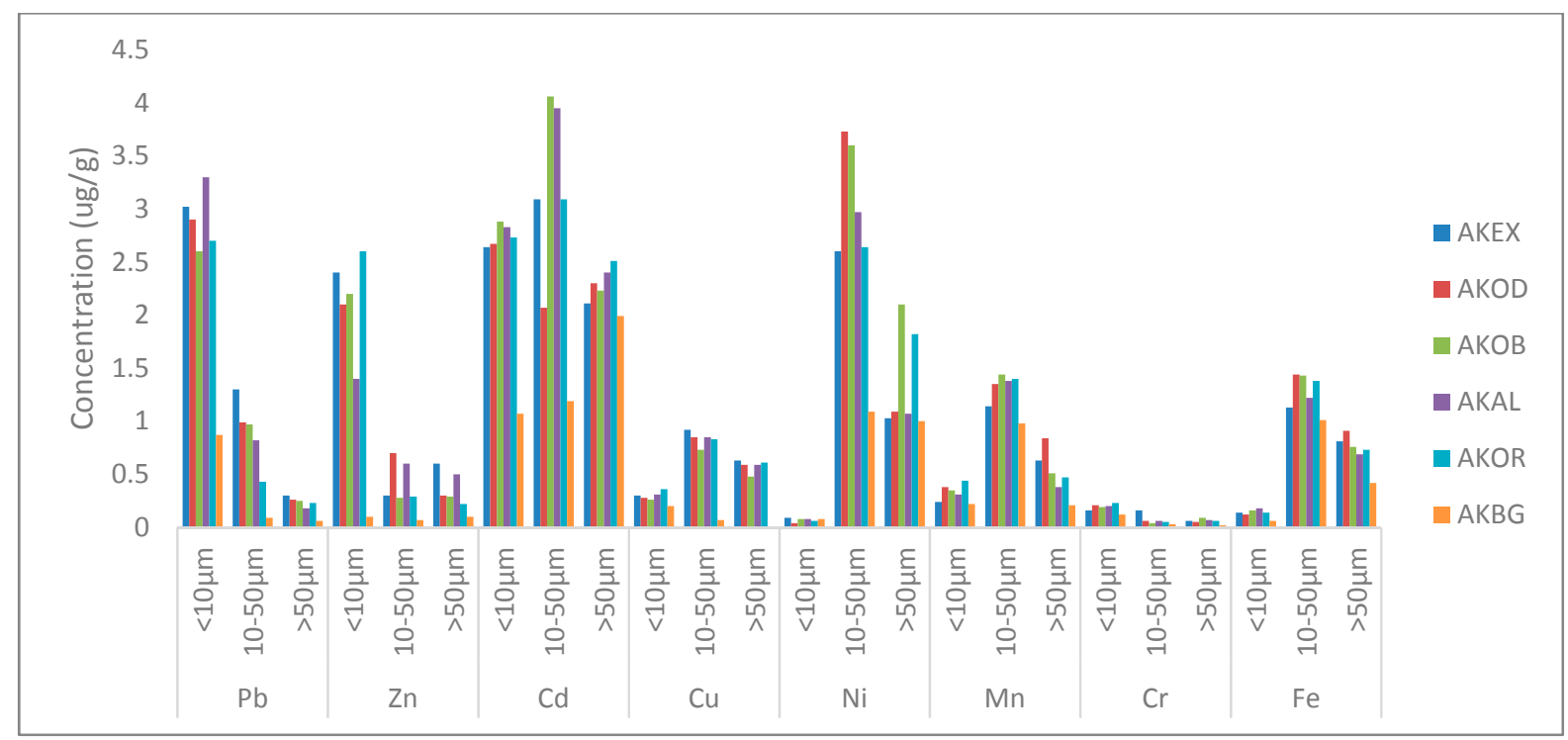

Figure 1: Distribution of Metals (ug/g) in different Particle sizes at Akure sampling sites

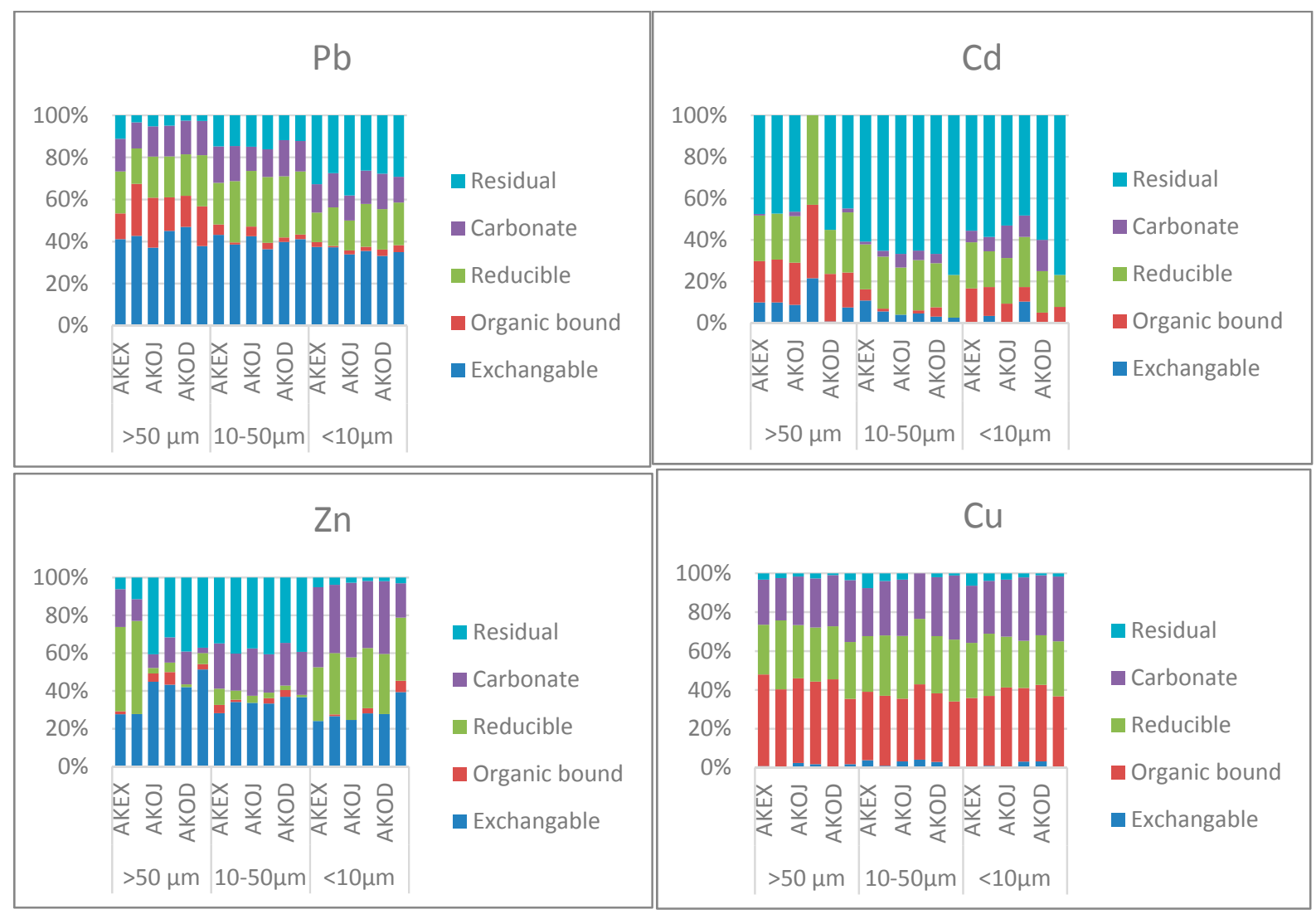




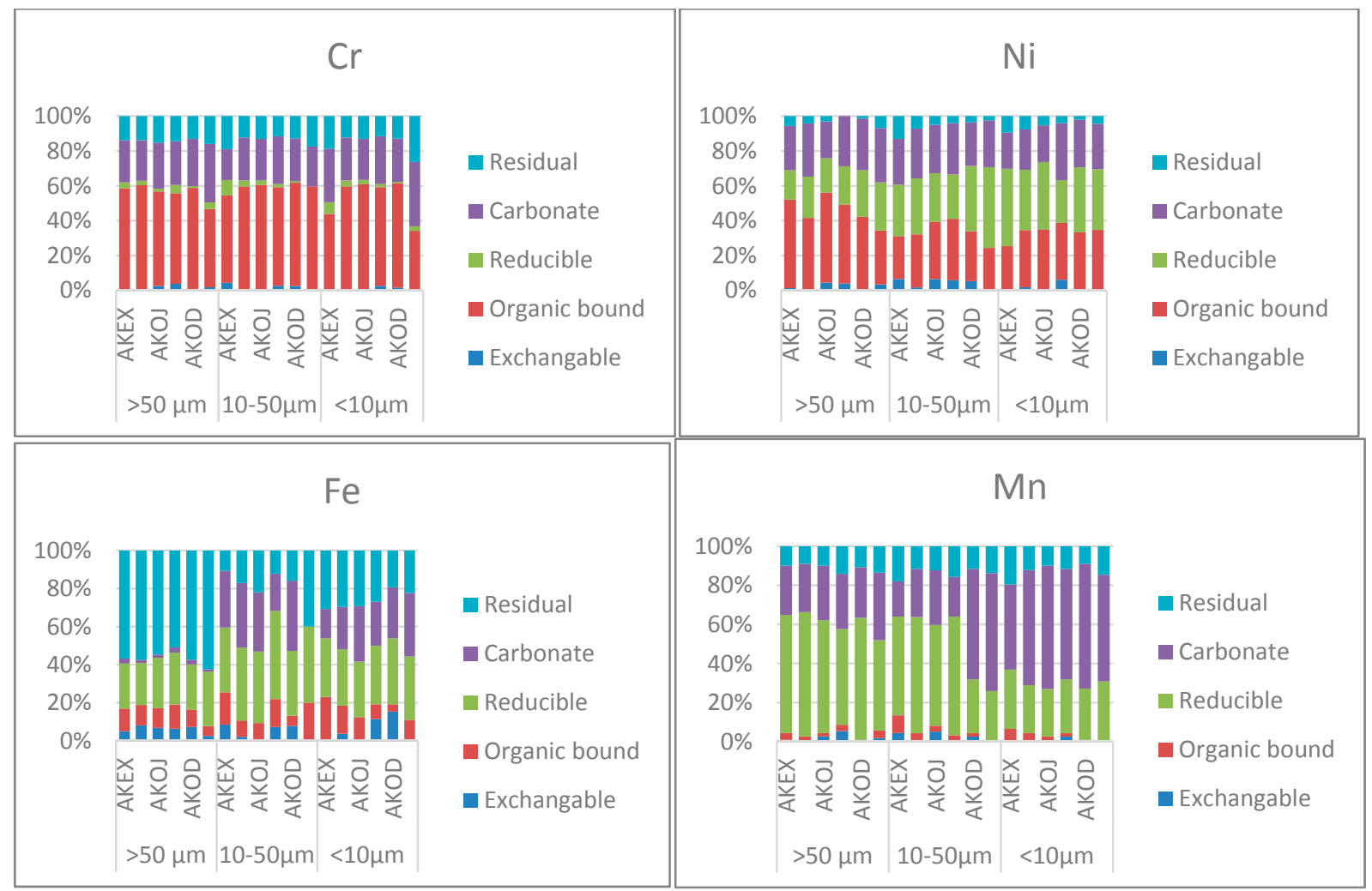

Figure 2: Speciation patterns of metals in dust particles at different geochemical phases

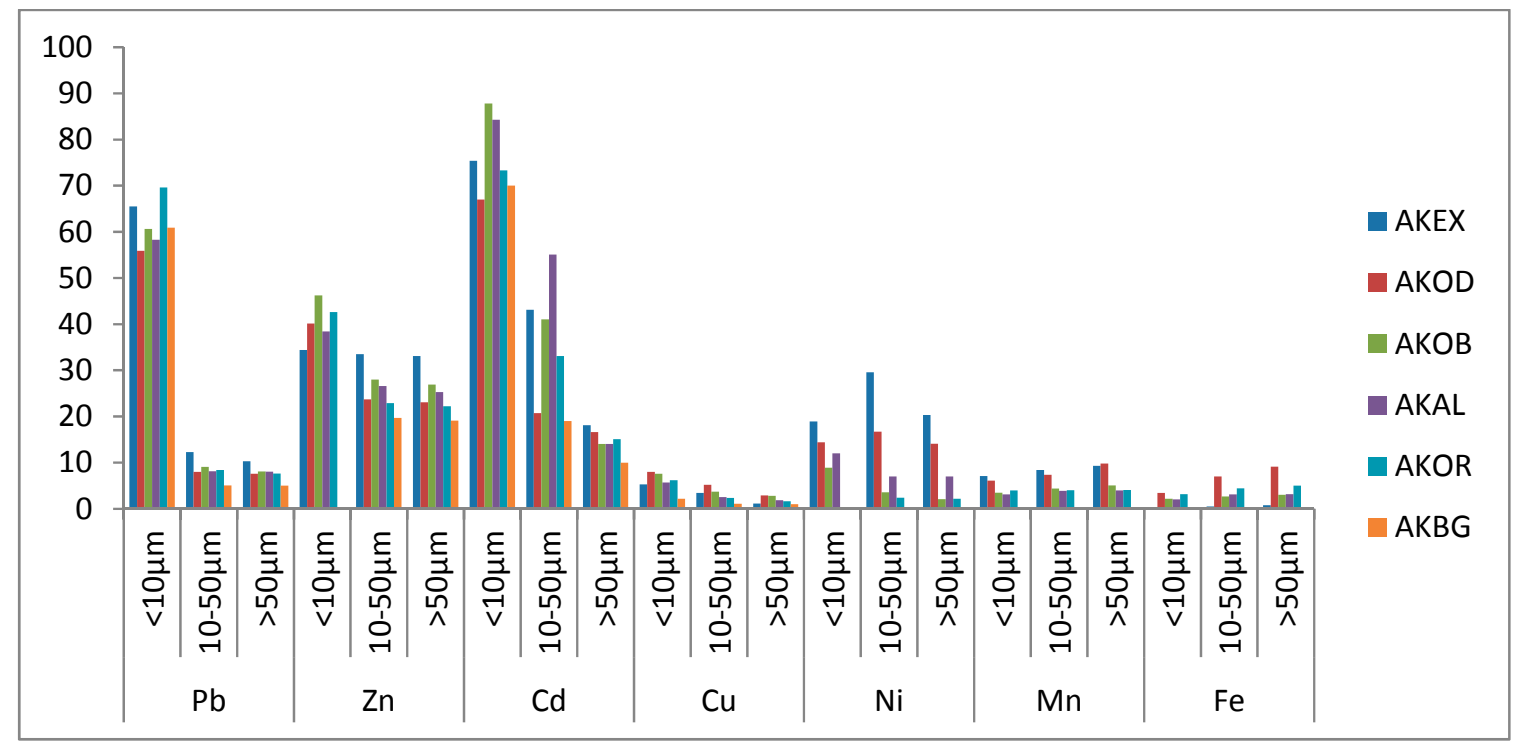

Figure 3: Relative bioavailability of the various metals using two-step physiological extraction (PBET) 